\title{
Past infestations of the white pine weevil in naturally regenerated spruce stands
}

\author{
by Troy T.M. Kimoto ${ }^{1,2}$, Rene I. Alfaro ${ }^{3}$ and John H. Borden ${ }^{1}$
}

Past infestations of the white pine weevil, Pissodes strobi (Peck), were reconstructed by examining standing and felled trees in naturally regenerated interior spruce stands in the McGregor Model Forest in northern B.C. Infestations were common in both the SubBoreal Spruce (SBS), wet cool (SBSwk) and very wet cool (SBSvk) biogeoclimatic subzones, demonstrating that frequent weeviling is a natural event that predates human intervention. Approximately one-third of all stem defects in 32 felled trees were verified as caused by the weevil. In the SBSwk and SBSvk $56.3 \%$ and $81.3 \%$ of felled trees contained weevil-caused defects, with 1.9 and 2.1 defects per tree, respectively. Trees in the SBSvk had significantly more weevil attacks high on the bole than trees in the SBSwk.

Key words: white pine weevil, Pissodes strobi, white spruce, Engelmann spruce, Picea engelmannii $\times$ P. glauca

Les épidémies antérieures du charançon du pin blanc, Pissodes strobi (Peck), ont été reconstituées par l'examen des arbres debout et abattus dans les peuplements de l'intérieur régénérés naturellement d'épinettes dans la Forêt modèle de McGregor. Les épidémies ont été retrouvées tant dans les sous-zones biogéoclimatiques de l'épinette sub-boréale (SBS), que pour les sous-zones fraîches et humides (SBSwk) et fraîches et très humides (SBSvk), illustrant que les épidémies fréquentes de charançon constituent un événement naturel qui date d'avant l'intervention humaine. Près du tiers de toutes les tiges défectueuses des 32 arbres abattus ont été identifiées comme ayant été attaquées par le charançon. Dans les sous-zones SBSwk et SBSvk, 56,3\% et 81,3\% des arbres abattus contenaient des défauts provoqués par le charançon, atteignant pour chaque sous-zone, 1,9 et 2,1 défauts par arbre. Les arbres de la sous-zone SBSvk ont connu significativement plus d'attaques du charançon haut sur la tige que dans le cas des arbres de la sous-zone SBSwk.

Mots-clés: charançon du pin blanc, Pissodes strobi, épinette blanche, épinette d'Engelmann, Picea engelmannii $\times$ P. glauca

\section{Introduction}

Forest landscape structure is shaped by two general processes: natural disturbance regimes, including stand-replacing or stand-maintaining wildfires and forest management activities including silvicultural treatments and harvesting. Within much of the British Columbia (B.C.) interior, clearcutting has surpassed stand-replacing fires as the most dominant disturbance agent (Delong and Tanner 1996).

Understanding the effects of forest management practices on insect pests is important if stand productivity is to be maintained or increased. However, such an understanding requires background knowledge of pest history in naturally regenerated forests. This is particularly important if forest management activities are to emulate natural disturbances as currently recommended by some ecologists. It is assumed that indigenous flora and fauna are better adapted to natural than to humancaused disturbance regimes and that the adverse impacts of forest practices may be minimized if they mimic natural disturbances (Hansen et al. 1991, Swanson et al. 1994, Delong and Tanner 1996).

For some insects it is possible to reconstruct the history of infestations in naturally regenerated stands. For example, outbreaks of defoliating lepidoptera can be tracked by episodic reductions in the width of tree rings caused by reduced photosynthetic capacity during periods of intense defoliation (Alfaro et al. 1982). Changes in neighbouring tree ring widths can be

\footnotetext{
${ }^{1}$ Centre for Environmental Biology, Department of Biological Sciences, Simon Fraser University, Burnaby, BC V5A 1 S6.

2Present address: Phero Tech Inc., 7572 Progress Way, RR\#5, Delta, BC V4G IE9 Canada.

${ }^{3}$ Pacific Forestry Centre, Canadian Forest Service, 506 West Burnside Road, Victoria, BC V8Z 1M5.
}

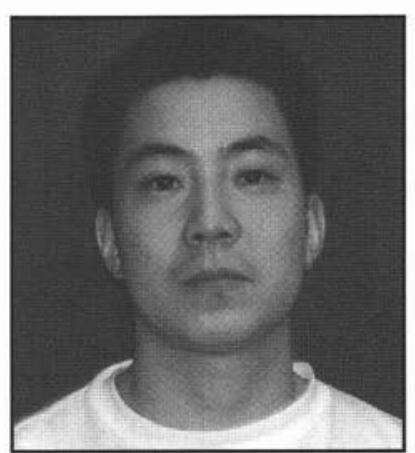

Troy Kimoto

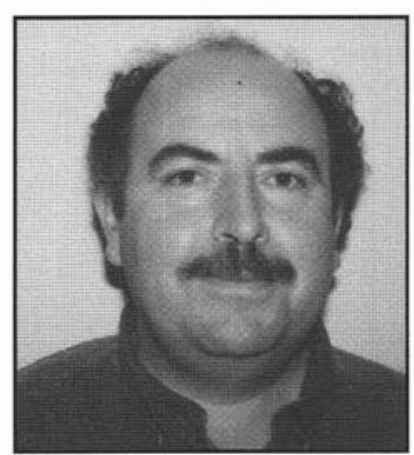

Rene Alfaro used to determine the occurrence of past outbreaks of bark beetles (Heath and Alfaro 1990, Veblen et al. 1991). It is also possible to reconstruct the retrospective stand epidemiology of the white pine weevil, Pissodes strobi (Peck), because most attacks leave a killed leader and a characteristic deformation in the bole of the tree (Alfaro 1989), both of which long remain visible on

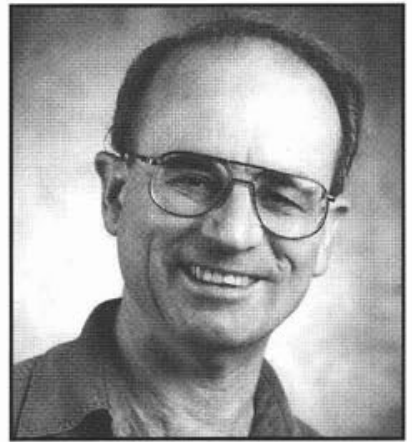

John Borden trees, sometimes into maturity.

In the interior of B.C., the white pine weevil is a serious pest of young white spruce, Picea glauca (Moench) Voss, Engelmann spruce, Picea engelmannii (Parry) Engelm., and "interior" spruce, $P$. engelmannii $\times P$. glauca, growing in the zone of hybridization (Meidinger and Pojar 1991, Coates et al. 1994) between Engelmann and white spruce. The weevil 
begins to attack susceptible spruce plantations as young as four to five years old; maximal attack intensities (numbers of trees attacked per year) occur in 10-30 year old stands. In plantations more than 30 years old, attack intensities gradually decline as the stand matures (Alfaro and Omule 1990). This decline may be caused by intraspecific competition between trees that reduces terminal leader size and thus food supply, by changes in leader microclimate, or by a decrease in susceptibility to the weevil (Alfaro 1994).

Model Forests have recently been established across Canada ${ }^{4}$. In these forests, research on socio-economic factors, ecological processes and forest practices is intended to facilitate the development and adoption of forest management strategies and decision support systems that will aid in sustainable resource management. The McGregor Model Forest, which encompasses Canadian Forest Products Ltd. Tree Farm License 30 , is an approximately 165000 ha management unit, located $100 \mathrm{~km}$ northeast of Prince George, B.C. It is comprised of four biogeoclimatic zones (Meidinger and Pojar 1991): Interior Cedar-Hemlock, Engelmann Spruce-Subalpine Fir, Alpine-Tundra, and Sub-Boreal Spruce (SBS). The Model Forest includes 33000 ha of immature forests, primarily in the SBS zone, which are at risk to weevil attack.

The SBS zone has a continental climate characterized by long cold winters and relatively warm moist and short summers (Meidinger et al. 1991, Coates et al. 1994). Mean annual temperatures range from $1.7-5.0^{\circ} \mathrm{C}$ with mean temperatures less than $0^{\circ} \mathrm{C}$ for four to five months and more than $10^{\circ} \mathrm{C}$ for two to five months. Mean annual precipitation is $440-900 \mathrm{~mm}$ of which $25-50 \%$ falls as snow. Interior spruce is the dominant climax tree. Two of the 10 subzones, the wet cool and the very wet cool subzones (SBSwk and SBSvk, respectively, hereafter referred to without the terms "zone" or "subzone") occur in the McGregor Model Forest (Meidinger et al. 1991).

Stand-replacing fires are the dominant natural disturbance agents within the SBS (Delong and Tanner 1996). These fires eliminate most of the overstory vegetation, exposing the mineral soil, which favours interior spruce germination (Coates et al. 1994). Patches of young interior spruce then become established and, depending upon the weevil hazard for that stand (Spittlehouse et al. 1994), can be susceptible to white pine weevil attacks. However, the differences in weevil epidemiology between naturally regenerated forests after a fire and plantations after harvest is unknown.

Our objective was to reconstruct weevil attack history in naturally regenerated stands that occurred after natural wildfires in the SBSwk and SBSvk within and near the McGregor Model Forest. Reconstruction of past weevil attacks will allow forest managers to determine whether present day weevil infestations are brought about, intensified, or lessened by current forest management practices. A companion study in post-harvest plantations in the McGregor Model Forest is nearing completion (J.A. McLean, Faculty of Forestry, University of B.C., Vancouver, personal communication).

${ }^{4}$ Evaluation of the Canadian Model Forest Program, PE223/1996, May 1996. Report prepared by Gardner Pinfold Consulting Economists Ltd., Halifax for National Advisory Committee for the Model Forest Program Evaluation, Natural Resources Canada, Ottawa.

\section{Methods}

For each of the SBSvk and SBSwk, four sites containing naturally regenerated spruce as the numerically dominant species were selected (Table 1). Stand age ranged from 21 to 59 years; trees within each site were even-aged. Fire history was obtained from existing records and confirmed by the presence of charcoal in the soil and fire scars on the few remaining veteran trees. Two fixed-radius circular plot centres per stand were selected at least $20 \mathrm{~m}$ into the stand and at least 50 $\mathrm{m}$ apart. Plot radii were 11.28 or $12.61 \mathrm{~m}$, yielding plot areas of 399.7 and $499.6 \mathrm{~m}^{2}$, respectively (Watts 1983). The large plots were used when tree density was relatively low. Diameter at breast height ( $\mathrm{dbh}=1.3 \mathrm{~m})$ and crown class (dominant, codominant, intermediate, or suppressed) (Anonymous 1980) were recorded for all conifers at least $7.5 \mathrm{~cm}$ dbh. Elevation and aspect of each plot were determined using altimeter and compass.

The bole of each spruce tree within each plot was visually assessed from the ground for the type and approximate height of defects, classified as: scar, minor crooks, major crooks, and forks (Alfaro 1989). Ten dominant and codominant trees per plot were aged using increment borers and their height assessed using clinometers (Watts 1983).

To confirm whether defects were caused by weevil damage or some other factor, two dominant or codominant spruce trees per plot, each bearing abundant external evidence of defects, were selected to be felled. The height of each tree was recorded, and the type and height of all defects were noted, as were those defects associated with old terminal leaders containing pupal chambers or oviposition holes. Although other defects may be weevil-caused, only these latter defects provide proof of weevil attacks, unless the tree is dissected.

Data were analyzed using SAS $®$ (release 6.10) and Minitab ${ }^{\circledR}$ (release 10.1) statistical software packages. In all cases $\alpha=$ 0.05 . Student's t-Tests and Chi-square tests were used to determine respective differences in means or proportions between subzones. The frequency distributions of confirmed weevil attacks occurring at $2 \mathrm{~m}$ intervals along the bole were compared between subzones by a Chi-square test, with subzone as the independent variable and height of weevil attack as the dependent variable. The distributions of each type of weevil attack were also compared between subzones by a Chi-square test, with subzone and defect type as independent and dependent variables, respectively. The relationship between numbers of confirmed weevil attacks per felled tree and numbers of all defects as determined visually was analyzed by linear regression, pooling all felled trees in both subzones.

\section{Results}

Stand elevations ranged from $620-760 \mathrm{~m}$ in the SBSvk and $470-780 \mathrm{~m}$ in the SBSwk (Table 1). Stand densities were comparable (means of 1287 and 1231 stems per ha in the SBSvk and SBSwk, respectively) and the predominant trees were interior spruce (70.1 and 79.4\% in the SBSvk and SBSwk, respectively) (Table 1). The frequency distributions of interior spruce and subalpine fir within each crown class did not differ significantly within a species and subzone, but for pooled data, the distributions did differ significantly between species $\left(\chi^{2}=54.5 P=0.001\right)$. This was due primarily to differences in occupancy of dominant and suppressed classes. Twenty-six percent of all spruces were dominant and $13 \%$ were suppressed; 
Table 1. Characteristics of sampled stands within the Sub-Boreal Spruce biogeoclimatic zone in the McGregor Model Forest north of Prince George, B.C. Age calculated from 20 trees within two fixed radius plots per stand, and densities calculated from all dominant, codominant, intermediate and suppressed trees within the plots.

\begin{tabular}{|c|c|c|c|c|c|c|c|c|}
\hline \multirow{2}{*}{$\begin{array}{l}\text { Biogeoclimatic } \\
\text { subzone }^{\mathrm{a}}\end{array}$} & \multirow{2}{*}{$\begin{array}{c}\text { Stand } \\
\text { no. }{ }^{b}\end{array}$} & \multirow[b]{2}{*}{ Coordinates } & \multirow{2}{*}{$\begin{array}{l}\text { Elevation } \\
(\mathbf{m})\end{array}$} & \multirow[b]{2}{*}{ Aspect } & \multirow{2}{*}{$\begin{array}{c}\text { Stand } \\
\text { height }(\mathbf{m}) \\
(\bar{x} \pm \mathrm{SE})\end{array}$} & \multirow{2}{*}{$\begin{array}{c}\text { Stand } \\
\text { age }(\mathbf{y r})\end{array}$} & \multicolumn{2}{|c|}{$\begin{array}{c}\text { Number of trees } \\
\text { per ha }\end{array}$} \\
\hline & & & & & & & all conifers & spruce \\
\hline \multirow[t]{4}{*}{ SBSvk } & 1 & $54^{\circ} 22^{\prime} \mathrm{N}, 122^{\circ} 18^{\prime} \mathrm{W}$ & 715 & north & $12.8 \pm 2.8$ & 34 & 988 & 688 \\
\hline & 2 & $54^{\circ} 24^{\prime} \mathrm{N}, 122^{\circ} 15^{\prime} \mathrm{W}$ & 760 & south & $18.1 \pm 3.8$ & 50 & 1614 & 1063 \\
\hline & 3 & $54^{\circ} 24^{\prime} \mathrm{N}, 122^{\circ} 14^{\prime} \mathrm{W}$ & 730 & flat & $13.9 \pm 3.4$ & 46 & 1276 & 1063 \\
\hline & 4 & $54^{\circ} 21^{\prime} \mathrm{N}, 122^{\circ} 15^{\prime} \mathrm{W}$ & 620 & flat & $9.1 \pm 2.2$ & 35 & 1271 & 791 \\
\hline \multirow[t]{4}{*}{ SBSwk } & 5 & $54^{\circ} 16^{\prime} \mathrm{N}, 122^{\circ} 23^{\prime} \mathrm{W}$ & 780 & west & $22.4 \pm 3.9$ & 58 & 1777 & 1439 \\
\hline & 6 & $53^{\circ} 54^{\prime} \mathrm{N}, 122^{\circ} 20^{\prime} \mathrm{W}$ & 470 & flat & $24.5 \pm 2.6$ & 57 & 971 & 891 \\
\hline & 7 & $53^{\circ} 54^{\prime} \mathrm{N}, 122^{\circ} 20^{\prime} \mathrm{W}$ & 620 & west & $8.6 \pm 1.9$ & 21 & 811 & 520 \\
\hline & 8 & $54^{\circ} 01^{\prime} \mathrm{N}, 122^{\circ} 27^{\prime} \mathrm{W}$ & 680 & north & $24.6 \pm 4.2$ & 59 & 1364 & 1063 \\
\hline
\end{tabular}

asub-boreal spruce (SBS) very wet cool subzone (vk) and SBS wet cool subzone (wk).

bStand nos. 7 and 8 were ca. $40 \mathrm{~km}$ south of the McGregor Model Forest.

Table 2. Frequency of attack by the white pine weevil on naturally regenerated spruce in two biogeoclimatic subzones of the McGregor Model Forest.

\begin{tabular}{|c|c|c|c|c|c|c|c|}
\hline \multirow{2}{*}{$\begin{array}{l}\text { Category } \\
\text { of tree }\end{array}$} & \multicolumn{2}{|c|}{$\begin{array}{c}\text { Number of trees } \\
\text { examined }\end{array}$} & \multirow[b]{2}{*}{ Criterion assessed } & \multirow[b]{2}{*}{ SBSwk } & \multirow[b]{2}{*}{ SBSvk } & \multirow{2}{*}{\multicolumn{2}{|c|}{$\begin{array}{l}\text { Statistical evaluation } \\
\text { between subzones }\end{array}$}} \\
\hline & SBSvk & SBSwk & & & & & \\
\hline \multirow[t]{3}{*}{ Standing } & 306 & 344 & Percent of spruce with defects detected by visual assessment & $39.8 \%$ & $44.4 \%$ & $\chi^{2}=1.79$ & $P=0.181$ \\
\hline & 306 & 344 & $\begin{array}{l}\text { Mean }( \pm \mathrm{SE}) \text { number of defects per spruce tree detected by } \\
\text { visual assessment }\end{array}$ & $0.56 \pm 0.86$ & $0.70 \pm 0.96$ & $\mathrm{t}=1.93$ & $P=0.054$ \\
\hline & 59 & 62 & $\begin{array}{l}\text { Mean }( \pm \mathrm{SE}) \text { annual spruce height growth }(\mathrm{m} / \mathrm{yr}) \\
\text { (tree height/tree age) }\end{array}$ & $0.42 \pm 0.05$ & $0.33 \pm 0.08$ & $\mathrm{t}=-7.18$ & $P=0.000$ \\
\hline \multirow[t]{6}{*}{ felled } & 16 & 16 & Percent of trees with defects & $100.00 \%$ & $100.00 \%$ & & \\
\hline & 16 & 16 & Percent of spruce with defects verified as weevil-caused & $56.3 \%$ & $81.3 \%$ & $\chi^{2}=2.33$ & $P=0.127$ \\
\hline & 16 & 16 & Percent of all defects verified to be weevil-caused & $31.2 \%$ & $31.8 \%$ & $\chi^{2}=0.01$ & $P=0.936$ \\
\hline & 16 & 16 & Mean $( \pm$ SE) number of defects per spruce tree & $6.0 \pm 1.7$ & $6.7 \pm 2.7$ & $\mathrm{t}=0.88$ & $P=0.387$ \\
\hline & 16 & 16 & $\begin{array}{l}\text { Mean }( \pm \text { SE) number of defects per spruce tree verified } \\
\text { as weevil-caused }\end{array}$ & $1.9 \pm 2.0$ & $2.1 \pm 1.7$ & $\mathrm{t}=0.38$ & $P=0.709$ \\
\hline & 16 & 16 & Mean $( \pm$ SE) height $(m)$ on spruce bole of first weevil attack & $3.30 \pm 1.13$ & $5.67 \pm 2.47$ & $t=3.02$ & $P=0.007$ \\
\hline
\end{tabular}

for subalpine fir the respective percentages were 10 and $34 \%$. Stands in the SBSvk were $32.5 \%$ shorter than in the SBSwk. However, only a portion of this difference was due to differences in stand age (means of 41.3 and 48.8 years in the SBSvk and SBSwk, respectively), because trees in the colder SBSvk grew $20 \%$ less rapidly than in the SBSwk (means of 0.33 and $0.42 \mathrm{~m}$ of vertical growth per year in the SBSvk and SBSwk, respectively) (Table 2).

Large proportions of the naturally regenerated felled spruce trees in both subzones contained defects that arose from weevil attacks (Table 2). On average, a naturally regenerated interior spruce could be expected to sustain two weevil attacks in its lifetime. These results indicate that in the absence of human intervention, a high incidence of weevil infestation is a natural occurrence in the SBS.

There was a significant, but very weak relationship between the numbers of defects detected before felling and the number of confirmed weevil attacks per tree $\left(y=0.8 x+0.4, r^{2}=0.006\right.$, $P<0.006$ ), indicating that mature trees must be felled to obtain accurate estimates of past weevil attack.

Distributions of height of weevil attack on the bole differed significantly between subzones (Fig. 1). In both subzones most attacks were between 2 and $16 \mathrm{~m}$ high, but there were fewer weevil attacks low and more attacks high on the bole for trees growing in the SBSvk, the wetter and cooler subzone. The height of first weevil attack was also significantly lower in the
SBSwk than in the SBSvk (Table 2). On felled trees, neither the total number of defects nor the number of weevil-caused defects differed significantly between the two subzones (Table 2). Weevils caused approximately one third of all defects per felled tree in both subzones. However, only $56.3 \%$ of spruce trees with defects in the SBSwk had verified weevil-caused defects compared to $81.3 \%$ on spruce trees in the SBSvk (Table 2).

Distances to the four closest openings ranged from 100-3000 $\mathrm{m}$ from the sampled stands (Table 3 ). In almost every case the openings occurred from logging more than 30 years after the sample stand was established, well beyond the 30 -year window of susceptibility of the sample stands, ruling out the possibility of invasion of weevils from man-made disturbances. However, for stand number 7 the 30 -year susceptibility window overlapped that of the disturbed areas by 14 to 24 years. The 24-year overlap occurred for an opening $2000 \mathrm{~m}$ distant, and it would probably have taken 5 to 10 years for a sufficient number of migrating weevils to have emerged from that site and found the sample stand.

Differences in the frequency distributions of each type of weevil-caused defect between subzones approached significance (Fig. 2). Minor crooks were the predominant defect in both subzones. Trees in the SBSvk had almost equal numbers of scars, major crooks, and forks, while those in SBSwk had very few scars or forks. 


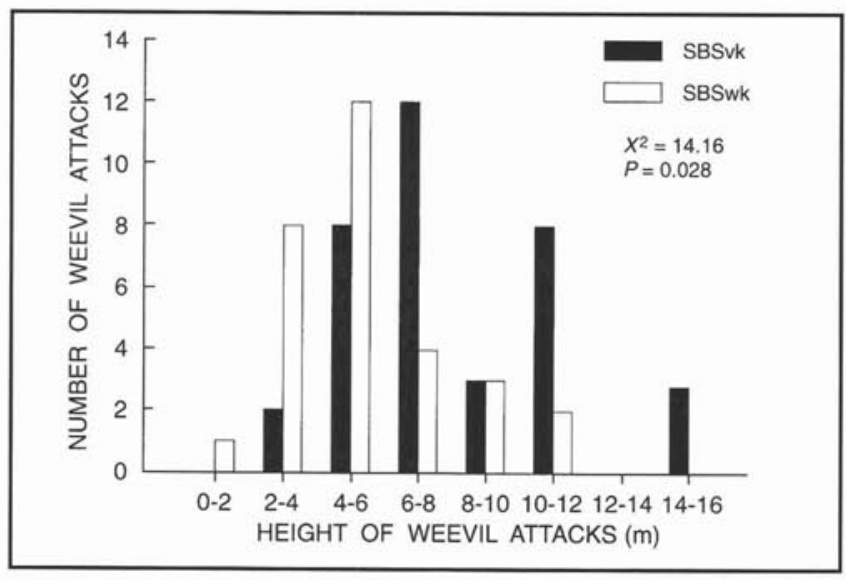

Fig. 1. Distributions of weevil attacks by height on the bole of interior spruce in the SBSvk and SBSwk biogeoclimatic subzones.

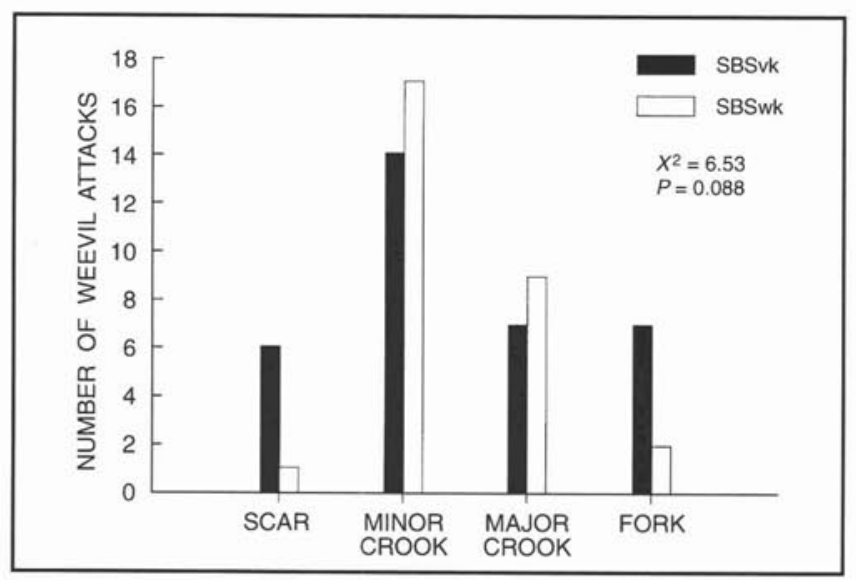

Fig. 2. Frequency distributions of type of defect caused by white pine weevil attack in the SBSvk and SBSwk biogeoclimatic subzones.

\section{Discussion}

In mature undisturbed Sitka spruce forests along the B.C. coast, attacks by the white pine weevil are rare (Alfaro 1994). In the coastal fog belt accumulated degree days during the summer are too low to sustain weevil development (McMullen 1976). However, in naturally regenerated spruce forests in the SBSvk and SBSwk weevil attacks were frequent and the damage substantial. Because some evidence for past weevil attacks may have been buried in the sapwood of mature trees, dissection of felled trees might have revealed an even higher incidence of attack. Thus, selection of trees with obvious defects for felling may have been offset by a conservative measure of the number of attacks. However, even on external examination, the record held by trees many years after attack provides irrefutable evidence that the white pine weevil has been a prevalent natural component of these sub-boreal forest ecosystems that predated human intervention. This conclusion is consistent with the findings of Alfaro (1996) in fire-regenerated stands near Williams Lake, more than $200 \mathrm{~km}$ south of our study sites, and is supported by the evidence in Table 3 that it is impossible or (in one case) extremely unlikely that weevils in the sampled stands could have originated in sites disturbed by mankind. It also conforms with calculations based on recorded climatic data
Table 3. Relationship of sampled stands (Table 1) to four nearest openings from which migrating weevils could have originated.

\begin{tabular}{|c|c|c|c|}
\hline $\begin{array}{l}\text { Stand } \\
\text { no. }\end{array}$ & $\begin{array}{c}\text { Distance to four } \\
\text { nearest openings } \\
\text { disturbed by logging } \\
\text { or burning }(\mathrm{m})\end{array}$ & $\begin{array}{c}\text { Date of } \\
\text { disturbance }\end{array}$ & $\begin{array}{l}\text { Duration to first possible } \\
\text { weevil attack in disturbed } \\
\text { area after sample stand } \\
\text { established (years) }\end{array}$ \\
\hline \multirow[t]{4}{*}{1} & 350 & 1990 & 29 \\
\hline & 1350 & 1993 & 32 \\
\hline & 2400 & 1989 & 28 \\
\hline & 2770 & 1994 & 33 \\
\hline \multirow[t]{4}{*}{2} & 930 & 1994 & 49 \\
\hline & 1130 & 1989 & 44 \\
\hline & 1350 & 1989 & 44 \\
\hline & 1500 & 1994 & 49 \\
\hline \multirow[t]{4}{*}{3} & 300 & 1989 & 40 \\
\hline & 400 & 1994 & 45 \\
\hline & 1050 & 1994 & 45 \\
\hline & 2150 & 1989 & 40 \\
\hline \multirow[t]{4}{*}{4} & 1000 & 1996 & 36 \\
\hline & 1140 & 1995 & 35 \\
\hline & 1350 & 1994 & 34 \\
\hline & 1650 & 1995 & 35 \\
\hline \multirow[t]{4}{*}{5} & 250 & 1980 & 43 \\
\hline & 750 & 1979 & 42 \\
\hline & 900 & 1998 & 61 \\
\hline & 950 & 1981 & 44 \\
\hline \multirow[t]{4}{*}{6} & 100 & 1956 & 18 \\
\hline & 300 & 1959 & 21 \\
\hline & 800 & 1977 & 39 \\
\hline & 1600 & 1981 & 43 \\
\hline \multirow[t]{4}{*}{7} & 550 & 1991 & 16 \\
\hline & 650 & 1990 & 15 \\
\hline & 1500 & 1991 & 16 \\
\hline & 2000 & 1980 & 6 \\
\hline \multirow[t]{4}{*}{8} & 100 & 1994 & 58 \\
\hline & 1200 & 1994 & 58 \\
\hline & 1600 & 1995 & 59 \\
\hline & 3000 & 1971 & 35 \\
\hline
\end{tabular}

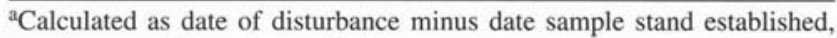
based on age of trees in sample plot.

that unshaded leaders and, in some years shaded leaders, in all sampled stands accumulated more than 785 degree days (B.G. Sieben, Faculty of Forestry, University of British Columbia, Vancouver, personal communication), enough heat accumulation to allow for successful weevil development.

The lower height of the first weevil attack on spruce boles in the SBSwk than in the SBSvk suggests that weevils may initiate attacks on younger or smaller spruce trees in the SBSwk than in the SBSvk. Because wood volume is greatest near the base, the quantity of defect-free timber obtained from stands in the SBSwk may thus be less than from SBSvk. However, this reduction in timber volume and quality may be offset by the large number of forks per felled tree on spruces growing in the SBSvk. Severe defects (major crooks and forks) accounted for $38 \%$ and $41 \%$ of all defects in the SBSwk and SBSvk, respectively. In eastern white pine, Pinus strobus L., Brace (1972) calculated that such defects reduced the value of lumber recovered from attacked trees by $25 \%$. If similar losses are sustained in naturally-regenerated interior spruce, as appears 
likely, effective weevil management in managed plantations could greatly increase the value of the trees at harvest.

As expected (Alfaro and Omule 1990), weevil attacks in relation to height on the bole were more or less normally distributed in both subzones. The higher extent of attacks on the bole in the SBSvk than in the SBSwk could be explained by three hypotheses, among others. Firstly there may be less overstory shade in the SBSvk than in the SBSwk. Although not counted or measured, paper birch, Betula papyrifera Marsh, black cottonwood, Populus trichocarpa Torr. and Gray, and trembling aspen, Populus tremuloides Michx., were present as dominants or co-dominants in three of the four SBSwk sites, but were absent in all SBSvk sites. These trees might have provided sufficient shade during the early life of a stand in the SBSwk to limit most attacks to a height of $8 \mathrm{~m}$ or less (Taylor and Cozens 1994, Taylor et al. 1996). Secondly, small leaders in the SBSvk may have negatively affected larval growth, and produced small adults with limited fat reserves. Like bark beetles (Atkins 1975, Hagen and Atkins 1975, Jactel 1993) adult weevils with low lipid content might not have had the metabolic capacity to disperse to new habitats, extending the duration and raising the height of attacks in the SBSvk. Thirdly, in the McGregor Model Forest the natural return interval for standreplacing fires (Delong and Tanner 1996) within the SBSvk is estimated to be 500 to 700 years (B.C. Hawkes, Canadian Forest Service, Pacific Forestry Centre, Victoria, B.C., personal communication), which would result in only $0.14 \%$ of this subzone burning every year. The fire return interval in the SBSwk is unknown, but presumably shorter than in the SBSvk (B.C. Hawkes, personal communication). Therefore, weevils in the SBSvk may accept and remain in ageing stands and attack very high leaders, while in the SBSwk many patches of young stands would be created per unit time and would be available as new habitats for dispersing weevils that departed from ageing stands.

We suggest that surveys for weevil-caused defects in fireregenerated mature trees could be used to supplement hazard rating based on climate and elevation (Spittlehouse et al. 1994, Taylor 1997) as a basis for weevil management plans that could be incorporated into silvicultural prescriptions. Forests that have a high hazard rating may warrant a silvicultural prescription that includes planting of weevil-resistant trees (Kiss et al. 1994, Alfaro et al. 1996), high density planting, and a mixing of spruce with a deciduous overstory (Taylor and Cozens 1994, Alfaro et al. 1995, Taylor et al. 1996).

\section{Acknowledgements}

We thank the McGregor Model Forest Association for providing the opportunity to work on the Model Forest, R.C. Brooke for advice and review of an earlier draft of the manuscript, E. Wegwitz and C. Horvath for assisting in data collecting, R.A. Doratty and R. Jarvis, Canadian Forest Products Ltd., for assistance in locating sample sites, and providing dates of disturbances, respectively, R. Benton for contributing retrospective climate data, B.C. Hawkes for assistance in site selection and contributing fire history data, and B.G. Sieben for contributing hazard rating data. This research was supported by the McGregor Model Forest Association, the Canadian Forest Service, and the Natural Sciences and Engineering Research Council of Canada.

\section{References}

Alfaro, R.I. 1989. Stem defects in Sitka spruce induced by Sitka spruce weevil, Pissodes strobi Peck. In R.I. Alfaro and S. Glover (eds.). Insects affecting reforestation: biology and damage. Proceedings of a meeting of the IUFRO Working Group on Insects Affecting Reforestation. pp. 177-185. Forestry Canada, Victoria, B.C. 256 p.

Alfaro, R.I. 1994. The white pine weevil: biology and damage. In R.I. Alfaro, G. Kiss and R.G. Fraser (eds.). The white pine weevil: biology, damage, and management. Proceedings of a symposium held January 19-21, 1994, Richmond, B.C. pp. 7-22. Can. For. Serv. and B.C. Min. For., Victoria, B.C. FRDA Rep. No. 226. 311 p.

Alfaro, R.I. 1996. Role of genetic resistance in managing ecosystems susceptible to white pine weevil. For. Chron. 72: 374-380.

Alfaro, R.I., J.H. Borden, R.G. Fraser and A. Yanchuck. 1995. The white pine weevil in British Columbia: basis for an integrated pest management system. For. Chron. 71: 66-73.

Alfaro, R.I., G. He, G. Kiss, J. King and A. Yanchuk. 1996. The resistance of white spruce to white pine weevil: development of a resistance index. For. Ecol. Manage. 81: 51-62.

Alfaro, R.I. and S.A.Y. Omule. 1990. The effect of spacing on Sitka spruce weevil damage to Sitka spruce. Can. J. For. Res. 20: 179-184. Alfaro, R.I., G.A. Van Sickle, A.J. Thomson and E. Wegwitz. 1982. Tree mortality and radial growth losses caused by the western spruce budworm in a Douglas-fir stand in British Columbia. Can. J. For. Res. 12: 780-787.

Anonymous. 1980. Forest Service cruising procedures and cruise compilation. Ministry of Forests, Victoria.

Atkins, M.D. 1975. On factors affecting the size, fat content and behaviour of a scolytid. J. Appl. Entomol. 78: 209-218.

Brace, L.G. 1972. Weevil control could raise the value of white pine by $25 \%$. Can. For. Ind. $92: 42-45$.

Coates, K.D., S. Haeussler, S. Lindeburgh, R. Pojar and A.J. Stock. 1994. Ecology and silviculture of interior spruce in British Columbia. Can. For. Serv. and B.C. Min. For., Victoria, B.C. FRDA Rep. No. 220.

DeLong, S.C. and D. Tanner. 1996. Managing the patterns of forest harvest in sub-boreal, fire maintained landscapes. Biodiversity and Conservation. 5:1191-1205.

Hagen, B.W. and M.D. Atkins. 1975. Between generation variability in the fat content and behaviour of Ips paraconfusus Lanier. J. App. Entomol. 79: 169-172.

Hansen, A.I., T.A. Spies, F.J. Swanson and J.L. Ohmann. 1991. Conserving biodiversity in managed forests: lessons from natural forests. Bio Sci. 41: 382-392,

Heath, R. and R.I. Alfaro. 1990. Growth response in a Douglasfir/lodgepole pine stand after thinning of lodgepole pine by the mountain pine beetle. J. Entomol. Soc. B.C. 87: 16-21.

Jactel, H. 1993. Individual variability of the flight potential of Ips sexdentatus Boern. (Coleoptera: Scolytidae) in relation to day of emergence, sex, size, and lipid content. Can. Entomol. 125: 919-930.

Kiss, G.K., A.D. Yanchuk and R.I. Alfaro. 1994. Recent advances in white pine weevil resistance in British Columbia. In R.I. Alfaro, G. Kiss and R.G. Fraser (eds.). The white pine weevil: biology, damage and management. Proceedings of a symposium held January 19-21, 1994, Richmond, B.C. pp. 150-157. Can. For. Serv. and B.C. Min. For., Victoria, B.C. FRDA Rep. No. 226. 311 p.

McMullen, L.H. 1976. Spruce weevil damage. Ecological basis and hazard rating for Vancouver Island. Can. For. Serv. Pac. For. Res. Cen. Inf. Rep. BC-X-141. 7 p.

Meidinger, D. and J. Pojar. (eds.). 1991. Ecosystems of British Columbia. B.C. Min. For. Spec. Rep. Ser. No. 6. 33 p.

Meidinger, D., J. Pojar and W.L. Harper. 1991. Sub-Boreal Spruce zone. In D. Meidinger and J. Pojar. (eds.). Ecosystems of British Columbia. pp. 209-221. B.C. Min. For. Spec. Rep. Ser. No. 6. $330 \mathrm{p}$.

Spittlehouse, D.L., B.G. Sieben and S.P. Taylor. 1994. Spruce weevil hazard mapping based on climate and ground survey data. In R.I. 
Alfaro, G. Kiss and R.G. Fraser (eds.). The white pine weevil: biology, damage and management. Proceedings of a symposium held January 19-21, 1994, Richmond, B.C. pp. 23-32. Can. For. Serv. and B.C. Min. For., Victoria, B.C. FRDA Rep. No. 226. 311 p.

Swanson, F.J., J.A. Jones, D.O. Wallin and J.H. Cissel. 1994. Natural variability - Implications for ecosystem management. In M.E. Jensen and P.S. Bourgeron (eds.). Ecosystem management, principles and applications. Vol. II. Eastside forest ecosystem health assessment. pp. 80-94. USDA For. Serv. Gen. Tech. Rep. PNW-318.

Taylor, S.P. 1997. Relationships between white spruce vulnerability to the white pine weevil and ecological site conditions in the interior of British Columbia. M.Sc. Thesis. Univ. of Northern B.C., Prince George. 73 p.
Taylor, S.P. and R.D. Cozens. 1994. Limiting white pine weevil attacks by side and overstory shade in the Prince George Forest Region. J. Entomol. Soc. B.C. 91: 37-42.

Taylor, S.P., R.I. Alfaro, C. Delong and L. Rankin. 1996. The effects of overstory shading on white pine weevil damage to white spruce and its effects on spruce growth rates. Can. J. For. Res. 26: 306-312. Veblen, T.T., K.S. Hadley, M.S. Reid and A.J. Rebertus. 1991. Methods of detecting past spruce beetle outbreaks in rocky Mountain subalpine forests. Can. J. For. Res. 21: 242-254.

Watts, S.B. (ed.). 1983. Forestry Handbook for British Columbia. 4th Ed. The Forestry Undergraduate Society, Faculty of Forestry, University of British Columbia, Vancouver. 611 p. 